\title{
NAD WODAMI ZATOKI PERSKIEJ. BRYTYJSKO-OSMAŃSKIE STOSUNKI ZA PANOWANIA ABDÜLHAMIDA II (1876-1909)
}

\author{
ANDRZEJ MALINOWSKI
}

\begin{abstract}
Andrzej Malinowski, Nad wodami Zatoki Perskiej. Brytyjsko-osmańskie stosunki za panowania Abdülhamida II (On the shores of the Persian Gulf. British-Ottoman relations during the reign of Abdul Hamid II (1876-1909)).

British presence in the Gulf was seen by the Turks as a threat to their own economic interests and independence of the State. British politicians had expressed a very different point of view. The main purpose of this article is an attempt to present the relationship that have occurred between London and Constantinople during the reign of Abdülhamid II in this region and showing the effects of the British policy, which in some way limited the Ottoman sovereignty in the area.
\end{abstract}

SŁowA KLUCzowe: Zatoka Perska, Abdülhamid II, Półwysep Arabski, Imperium Osmańskie, Wielka Brytania

Balcanica Posnaniensia. Acta et studia, XXI, Poznań 2014, Wydawnictwo Instytutu Historii UAM, pp. 151-162, ISBN 978-83-63047-59-7, ISSN 0239-4278. Polish text with a summary in English.

Andrzej Malinowski, Akademia Pomorska w Słupsku, 76-200 Słupsk, ul. Arciszewskiego 21 a, malina72@interia.pl.

Wzrost strategicznego i ekonomicznego znaczenia Zatoki Perskiej był ściśle związany z pojawieniem się w tym rejonie Portugalczyków, którzy w XVI wieku dążyli do uczynienia Indii swoją strefą wpływów. Rozpoczął się wtedy trwający długie lata konflikt między Portugalią, Holandią i Francją z jednej strony, a Wielką Brytanią z drugiej o przejęcie całkowitej kontroli nad tym regionem. Wraz z Portugalczykami w walkę o hegemonię nad Zatoką Perską włączyło się także imperium osmańskie. Za czasów panowania Sulejmana I (1520-1566) Turcy podbili Arabię i rejon Zatoki Perskiej w celu powstrzymania zwiększających się wpływów portugalskich. Jednakże z upływem czasu oddziaływanie osmańskie w rejonie zatoki zaczęły maleć, a pozycję lidera spośród wszystkich zainteresowanych państw w XIX wieku przejęła Wielka Brytania.

Obecność Brytyjczyków w tym rejonie imperium osmańskiego Turcy odbierali jako bezpośrednie zagrożenie dla własnych, szeroko pojętych interesów. Z kolei Anglicy, którzy od początku XIX wieku potwierdzili swoją supremację nad Zatoką Perską, argumentowali zainteresowanie tym regionem ochroną interesów brytyjskich w Indiach ${ }^{1}$. Zręcznie wykorzystali niebezpieczeństwo płynące ze strony piratów, za-

${ }^{1} \mathrm{O}$ stosunkach brytyjsko-osmańskich w całym XIX wieku szerzej zob. A. Malinowski, Europejskie posiadtości Turcji w polityce Wielkiej Brytanii (1903-1914), Słupsk 2014, s. 13-40. 
mieszkujących Wybrzeże Piratów (zwane także jako Oman Traktatowy lub Wybrzeże Traktatowe; dzisiejsze Zjednoczone Emiraty Arabskie) $)^{2}$. Piraci ci zapuszczali się aż na Ocean Indyjski, co w połowie XIX wieku zmusiło Wielką Brytanię do interwencji w obronie zachodnich flot handlowych. Brytyjczycy zniszczyli Ras al-Chajmę, potwierdzając w ten sposób swe panowanie na morzu. Doprowadziło to do zawieszenia broni w 1853 roku i Wybrzeże Piratów stało się wybrzeżem powierniczym. Wielka Brytania podpisała również tzw. umowę ochronną z Wybrzeżem Piratów, Omanem, Maskatem i Bahrajnem, która zawierała klauzulę, iż żadna część ich terytoriów nie może być włączana w struktury innego państwa oraz, co wydaje się być ważniejsze, żadne z tych państw nie mogło wchodzić w układy z państwem trzecim bez zgody Anglii. Można zatem powiedzieć, że panowanie brytyjskie w rejonie Zatoki Perskiej opierało się przede wszystkim na niedopuszczaniu innych potęg, w tym Turków, do zajęcia tego regionu.

Mimo oczywistej dominacji nad Zatoką Perska, elity brytyjskie traktowały Porte jako czynnik zagrażający supremacji Londynu. Zgodnie z linią tanzimatu ${ }^{3}$, w roku 1871 Turcy próbowali wzmocnić swoją obecność w zatoce poprzez uniemożliwienie Anglikom dokonania kolejnych podbojów północnych szajchatów Zatoki Perskiej, Iraku i Arabii. Celem ochrony dwu ostatnich rząd osmański skoncentrował się przede wszystkim na regionach Kuwejtu, Hasy, Kataru, Nadżalu (tur. Necdu) oraz Bahrajnu, usiłując $\mathrm{w}$ ten sposób przeciwstawić się rosnącym wpływom brytyjskim w tym regionie. Postawa osmańska odbierana była w Londynie za oczywiste naruszenie i zagrożenie interesów brytyjskich, co skutkowało dążeniem do podważenia autorytetu Konstantynopola w tym regionie.

Brytyjska obecność w rejonie Zatoki Perskiej oraz wynikające z tego zagrożenie autorytetu i interesów ekonomicznych państwa tureckiego wynikało z dwóch głównych przyczyn. Po pierwsze miało to związek z ogólną linią polityczną prowadzoną przez Wielką Brytanię w stosunku do Indii i Arabii. Po drugie, związane było ze wzrostem napięcia w rejonie Zatoki Perskiej, czego następstwem były z biegiem czasu pogarszające się stosunki między Anglią a imperium osmańskim.

Abdülhamid II w momencie objęcia władzy rządził państwem, którego przetrwanie opierało się na gwarancji i poparciu mocarstw europejskich. W tamtym okresie Wielka Brytania była zwolennikiem integralności terytorialnej państwa osmańskiego. Politycy osmańscy doskonale zdawali sobie sprawę z celów, do jakich dążyły mocarstwa, jednocześnie robili wszystko, by uniknąć udzielenia im bezpośredniego poparcia. Była to niebezpieczna gra, którą bezwzględnie starały się spożytkować najbardziej zainteresowane kraje. Wykorzystywały do tego kapitał pieniężny, działalność konsulatów i kupców, misjonarzy i ich statut, jako protektorów ludności chrześcijańskiej na terenie imperium. Turcy byli świadomi trudnej sytuacji w jakiej się znaleźli

${ }^{2}$ Więcej o prowadzonych konfliktach o wpływy w rejonie Zatoki Perskiej w tym okresie zob. J. Zdanowski, Emiraty wahhabickie. Z dziejów Arabii w latach 1745-1934, Warszawa 1993, s. 54-58.

${ }^{3} \mathrm{Na}$ temat reform w Turcji szczegółowo zob. B. Lewis, Narodziny nowoczesnej Turcji, Warszawa 1972, s. 102-163. 
i bezustannie szukali sposobów na zmianę niekorzystnego położenia, lecz za czasów panowania Abdülhamida II państwo osmańskie było zbyt słabe, by skutecznie przeciwstawić się rosnącym obcym wpływom na dworze sułtańskim. Pragnąc utrzymać się na tronie sułtan pogłębiał swoje uzależnienie od wielkich mocarstw, co w konsekwencji doprowadziło do kilku bezpośrednich interwencji w wewnętrzne sprawy tureckie, które w znacznym stopniu przyczyniły się do słabości Porty.

Wzrost zagrożenia coraz bardziej odczuwalny w tureckich kręgach politycznych związany był ze zmianą sytuacji międzynarodowej i polityki brytyjskiej zmierzających do zachowania integralności imperium osmańskiego. Jeszcze po wojnie krymskiej Wielka Brytania, za zgodą pozostałych wielkich mocarstw, była gwarantką poszanowania interesów tureckich, co w bezpośredni sposób przekładało się na utrzymanie międzynarodowego status quo. Jednakże widoczna zmiana polityki państw europejskich nastapiła podczas kryzysu bałkańskiego z lat 1875-1878, gdy Anglicy i pozostałe mocarstwa będące wcześniej w opozycji do Rosji, nie poparły Turcji w zwalczaniu ruchów narodowowyzwoleńczych w tej części imperium. Kolejnym czynnikiem mającym wpływ na zmianę polityki brytyjskiej wobec Turcji było otwarcie Kanału Sueskiego ${ }^{4}$, bowiem londyńskie kręgi polityczne doszły do wniosku, iż w powstałej sytuacji integralność Turcji nabrała drugoplanowego znaczenia. I wreszcie postawa Porty przyczyniła się do pogorszenia relacji na linii Londyn-Konstantynopol. Brytyjska opinia publiczna coraz głośniej domagała się ukarania Turków za okrucieństwa, jakich dopuszczali się na ludności chrześcijańskiej w Bułgarii i Armenii. Wielka Brytania od początkowego zwolennika integralności Turcji powoli zmieniała postawę. Brytyjczycy zdali sobie sprawę, że popieranie jedności państwa osmańskiego nie w pełni realizowało zabezpieczenie swoich interesów. Lord Salisbury był skłonny opuścić Konstantynopol i przekazać miasto oraz cieśniny Bosfor i Dardanele w ręce rosyjskie ${ }^{5}$. Innymi słowy, Salisbury twierdził, że popieranie Turcji jako państwa buforowego przeciwko Rosji na Bliskim Wschodzie było błędem, bowiem od momentu opanowania Egiptu przez Anglików, nie istniało bezpośrednie zagrożenie z ich strony interesów brytyjskich w Indiach ${ }^{6}$. Lord Salisbury, jako żarliwy propagator podziału Turcji, był przekonany o braku możliwości uzdrowienia władzy tureckiej i ponownego pojawienia się na arenie międzynarodowej Porty, jako równorzędnej potęgi ${ }^{7}$.

Kierunek zmian w polityce brytyjskiej ujawnił się początkowo w czasie obrad konferencji konstantynopolskiej w 1876 roku, a następnie podczas wojny rosyjsko-tureckiej 1877-1878. Kongres berliński z 1878 roku ukazał też, że Anglia, Rosja, Francja

\footnotetext{
${ }^{4}$ Szeroko zob. A. Bartnicki, Egipt i Sudan w polityce Wielkiej Brytanii 1882-1936, Warszawa 1974, s. 23-74.

${ }^{5}$ G. Troeller, The Birth of Saudi Arabia, Britain and the Rise of the House of Saud, London 1976, s. 7.

${ }^{6}$ K. Karpat, The Politicization of Islam, Reconstructing Identity, State, Faith, and Community in the Late Ottoman State, Oxford 2001, s. 146, 178; J. Goldberg, The Foreign Policy of Saudi Arabia, The Formative Years, 1902-1918, Cambridge 1986, s. 35.

${ }^{7}$ C. J. Lowe, The Reluctant Imperialists, British Foreign Policy, 1878-1902, vol. 1, London 1967, s. 31 .
} 
i Austro-Węgry dążyły do podziału Turcji. Taka sytuacja nie sprzyjała Porcie, bowiem narażała ją na bezpośrednią konfrontacje $\mathrm{z}$ wielkimi mocarstwami i z góry stawiała na przegranej pozycji. Uwidoczniło się to w decyzjach podjętych podczas obrad, kiedy odebrano Turcji dwie-piąte terytorium z jedną-piątą ludności. Jednocześnie, co ważniejsze pozostawiono Turków na pastwę losu, w kwestii granic na Bałkanach i Środkowym Wschodzie. Sułtan Abdülhamid II był świadom słabości militarnej swojego imperium i nie był w stanie skutecznie bronić granic swego państwa ${ }^{8}$. Dotyczyło to zwłaszcza obszaru Zatoki Perskiej, gdzie po 1878 roku Brytyjczycy wzmogli swoją działalność.

W pierwszych latach panowania Abdülhamida II, zarówno sam sułtan, jak również politycy i intelektualiści doszli do przekonania, iż polityka prowadzona przez Londyn względem ich państwa jest szkodliwa. Nawet wśród osmańskich anglofilów panowało podobne przeświadczenie. Kamil pasza, oddany anglofil, próbujący doprowadzić do ocieplenia stosunków między obu krajami, wyraźnie stwierdził, iż od czasów wojny krymskiej okoliczności uległy zmianie i na horyzoncie nie rysowało się żadne porozumienie. Zarówno sułtan, jak i jego doradcy dostrzegali, że jeśli Brytyjczycy będą swobodnie kontynuować swoją politykę, może to doprowadzić do końca rządów osmańskich w Europie i Bliskim Wschodzie oraz grozi ustanowieniem strefy wpływów, czego końcowym efektem może być całkowity rozbiór Turcji. Ale i Wielka Brytania nie była pewna zachowania Porty, bowiem poważnie obawiała się, iż ta, by nie dopuścić do realizacji planów angielskich, wejdzie w układ z Rosją czy Niemcami9

Sytuacja geopolityczna zmusiła sułtana do znany kursu politycznego względem swoich posiadłości na wschodzie. W przeciwieństwie do lat ubiegłych, Porta coraz większą uwagę skupiała na terytoriach arabskich i w nich upatrywała swojej przyszłości, jako rekompensaty za utracone terytoria $\mathrm{w} 1878 \mathrm{roku}^{10}$. Wraz z początkiem panowania Abdülhamida II znaczenie prowincji arabskich wzrosło na tyle, że zaczęto im przypisywać ważną rolę w Rocznikach (Salnames) i poświęcano dużo więcej uwagi, niż pozostałym obszarom. Sułtan zmierzał do wzmocnienia swoich wpływów w tych prowincjach, bowiem zdawał sobie sprawę, że regiony Arabii, Iraku i Zatoki Perskiej Brytyjczycy traktowali jako swoją strefę wpływów. Politycy osmańscy byli przekonani, że Londyn dążył do podporząadkowania sobie całej Arabii i włączenia jej do Indii ${ }^{11}$.

Opanowanie Egiptu przez Brytyjczyków w 1882 roku $^{12}$ uznano w Konstantynopolu za punkt zwrotny w stosunkach między obu krajami oraz jawny przejaw wro-

${ }^{8}$ F. A. K. Yasamee, Ottoman Diplomacy. Abdülhamid II and the Great Powers, 1878-1888, Istanbul 1996, s. 45.

${ }^{9}$ Ibidem, s. 33, 34.

${ }^{10}$ R. Kumar, India and The Persian Gulf Region, 1858-1907, A Study in British Imperial Policy, New York 1965, s. 124.

${ }^{11}$ T. Kuhn, Shaping and Reshaping Colonial Ottomanism: Contesting Boundaries of Difference and Integration in Ottoman Yemen, „Comparative Studies of South Asia and the Middle East”, 2007, vol. 27, no. 2 , s. 319.

12 Zob. S. J. Shaw, E. K. Shaw, Historia Imperium Osmańskiego i Republiki Tureckiej, t. 2, Warszawa 2012, s. 304-307. 
giej polityki względem imperium osmańskiego ${ }^{13}$. Abdülhamid II coraz bardziej powątpiewał w intencje Anglików dotyczące terytoriów arabskich. Wielka Brytania twierdziła, że zajęcie Egiptu miało bezpośredni związek z ochroną drogi do Indii po otwarciu Kanału Sueskiego. Z kolei Turcy przewidywali, że za pośrednictwem Egiptu Brytyjczycy przystapią do destabilizacji osmańskich prowincji arabskich. Nie były to bezpodstawne obawy, bowiem już wcześniej, Londyn zachęcał ludy zamieszkujące wybrzeża Morza Czerwonego i Zatoki Perskiej do wystapień przeciw władzy tureckiej $^{14}$.

Jednocześnie władze tureckie doszły do przekonania, że Brytyjczycy będą zachęcać ludy arabskie do dążeń separatystycznych oraz powołania konkurencyjnego kalifatu w Mekce czy Kairze ${ }^{15}$. Porta przewidywała, że Londyn zdoła podporządkować sobie Arabię i Irak i im powierzy przywilej kierowania światem muzułmańskim $^{16}$. Prognozy sułtana i jego doradców dotyczące linii politycznej prowadzonej przez Brytyjczyków w ogólnym zarysie spełniły się niemal dokładnie. Po 1882 roku Wielka Brytania podsycała nacjonalizm arabski i promowała ideę utworzenia kalifatu arabskiego. Posługiwała się w tej dziedzinie chrześcijańskimi Arabami jako ideologami nacjonalizmu arabskiego, a Kair służył jako centrum wydawnicze i kolporterskie nowo powstającego ruchu ${ }^{17}$.

Brytyjczycy zagrażali posiadłościom osmańskim w Arabii z czterech głównych obszarów będących pod ich wpływami: od zachodu; z Aden od południa; od wschodu z Maskatu i Bahrajnu i od północy za pośrednictwem plemion Ibn-i Pasida. Zwłaszcza regiony przybrzeżne Arabii uznano, jako dogodne punkty ekspansji wpływów brytyjskich. Mając to na uwadze, zwłaszcza Katar i Aden nadawały się znakomicie do obcej interwencji. Turcy przewidywali, że gdyby Brytyjczykom udało się przejać kontrolę nad tymi i innymi strategicznymi obszarami Zatoki Perskiej (Melka, Ceziret-ul Ebu Ali, Ebu Zinni i Maskat) z pewnością nie zadowoliliby się tymi nabytkami, ale podjęliby walkę o kontrolę nad całą Arabią, bowiem w polityce brytyjskiej stanowiła ona ważny węzeł lądowy na drodze do Indii. Władze osmańskie zdawały sobie sprawę z zagrożeń, jakie mogły wyjść z poszczególnych szajchatów arabskich, zwłaszcza w rejonie Zatoki Perskiej, do którego Anglicy przykładali większą wagę, aniżeli do pozostałych obszarów Arabii ${ }^{18}$.

Jak już wspomniano powyżej, na początku panowania Abdülhamida II, Wielka Brytania nie była już sojusznikiem imperium osmańskiego. Zmiana jej polityki ewaluowała od popierania integralności po całkowity rozbiór państwa tureckiego w przy-

${ }^{13}$ E. M. Earle, Turkey, The Great Powers, and the Baghdad Railway, A Study in Imperialism, New York 1966, s. 195.

${ }_{14}^{14}$ F. A. K. Yasamee, Ottoman Diplomacy..., s. 111.

${ }^{15}$ Ibidem, s. 27.

16 T. Buzpınar, Opposition to the Ottoman Caliphate in the Early Years of Abdülhamid II 1877-1882, „Die Welt des Islams” 1996, vol. 36, no. 1, s. 64.

${ }^{17}$ K. Karpat, The Politicization of Islam..., s. 184.

${ }^{18}$ F. F. Anscombe, The Ottoman Gulf: The Creation of Kuwait, Saudi Arabia and Qatar, New York 1997, s. 175. 
padku, gdyby Arabia i Irak dostały się w strefę wpływów lub stały się nawet koloniami brytyjskimi. Nie ulega więc wątpliwości, że Anglia miała ściśle skonkretyzowane plany względem tego regionu polegające na utworzeniu kalifatu arabskiego. Porta będąca świadoma zagrożeń ze strony Brytyjczyków, szukała możliwości realnego przeciwstawienia się im $\mathrm{m}$. in. poprzez zawarcie nowego sojuszu z innym mocarstwem gotowym do poparcia jej wewnętrznej integralności. Ponadto sułtan dążył do udaremnienia planów angielskich przy użyciu własnych środków, np. kalifatu i wpływów muzułmańskich w państwach zachodnich.

W kontekście pogarszających się wzajemnych relacji można stwierdzić, że wzmożona obecność Brytyjczyków w rejonie Zatoki Perskiej była naturalną konsekwencją ogólnie panującej sytuacji. Sułtan, gdzie tylko mógł przeciwstawiał się polityce Londynu. Obszar zatoki był tego jaskrawym i dobitnym przykładem. Z drugiej strony władze brytyjskie w Indiach zakładały, że ze względu na słabość militarną i ekonomiczną Porta zaakceptuje stawiane jej propozycje rozwiązań w rejonie zatoki. Co więcej, obecność brytyjskich oddziałów wojskowych w południowych szajchatach Zatoki Perskiej, stawiała Turków z północnej części w bardzo trudnym położeniu.

Zatoka Perska stanowiła jeden z najważniejszych obszarów, z których można było poszerzyć strefę wpływów na Arabię, Irak i inne tereny państwa osmańskiego biorąc pod uwagę imperializm brytyjski. A z punktu widzenia ekonomicznego rejon zatoki był ważnym rynkiem zbytu towarów znad Tamizy. Wielka Brytania pragnęła zabezpieczyć swój stan posiadania w zatoce i chronić swoje interesy poliyczno-ekonomiczne. Sprzyjało temu samo położenie zatoki, gdzie nie było wyraźnego podziału między lądem a wybrzeżem. Poza tym nie istniały tam granice polityczne jak w Europie, bowiem najważniejszą rolę odgrywały tradycyjne więzy plemienne.

Ingerencja brytyjska $\mathrm{w}$ rejonie Zatoki Perskiej miała na celu uniemożliwienie ewentualnemu rywalowi uzyskania pełnej dominacji w tym regionie, a co za tym idzie przejęcia kontroli nad szlakiem do Indii. Dlatego też obecność osmańską w Zatoce Perskiej Brytyjczycy traktowali, jako zagrożenie dla prowadzonej przez siebie polityki, a Konstantynopol uczynili głównym wrogiem ${ }^{19}$.

Biorąc pod uwagę kategorię strategicznych imperatywów zainteresowanie brytyjskie Zatoką Perską ściśle powiązane był z Indiami, a zabezpieczenie tego rejonu stanowiło dla Anglików nadrzędny cel. Lord Curzon, wicekról Indii w latach 1898-1905, zauważył, że brytyjska supremacja w Indiach była ściśle powiązana z dominacją w Zatoce Perskiej i utrata nad nią kontroli niechybne spowodowałaby koniec panowania $w$ Indiach ${ }^{20}$. Z tego powodu tak ważną sprawą stała się dla Wielkiej Brytanii ochrona drogi do Indii, również przed Osmanami. Powszechnie bowiem uważano, że obecność innego mocarstwa $\mathrm{w}$ rejonie zatoki może przysporzyć rządom brytyjskim w Indiach problemów z racji bliskości terytorialnej. Brytyjczycy obawiali się wpływu osmańskiego panislamizmu i ewentualnych reperkusji, jakie mógł on zro-

${ }^{19}$ Ibidem, s. 2, 4, 70.

${ }^{20}$ M. Yapp, British Policy in the Persian Gulf, w: The Persian Gulf States, A General Survey, red. C. E. Bosworth i in., Baltimore 1981, s. 82. 
dzić w Indiach ${ }^{21}$. Nie tylko ten ruch wywoływał poważne zaniepokojenie Anglików. Sen z powiek spędzała im również możliwość zawieszenia handlu niewolnikami, piractwo, niekontrolowany rozwój handlu oraz ochrona swoich interesów w Persji czy Mezopotamii. Należy nadmienić, że Anglicy uczynili z Zatoki Perskiej bramę do Persji i Mezopotamii, a te obszary swoją strefą wpływów.

Pomijając polityczne i strategiczne aspekty Zatoka Perska odgrywała ważną rolę również ze względu na ogromne korzyści ekonomiczne, jakie przynosiła państwu brytyjskiemu. Począwszy od XVII wieku obszar ten wraz z całą Arabią odgrywał istotną rolę w szybko rozwijającym się handlu z Indiami. Region ten stał się rynkiem zbytu dla produktów brytyjskich oraz odskocznią do pozostałych miejsc w Arabii i Iraku. Tak więc aspekt ekonomiczny Zatoki Perskiej został ściśle połączony z ekonomią atlantycka, gdzie Brytyjczycy posiadali ogromne wpływy.

Wielka Brytania była przekonana, że realizację swoich imperialnych i strategicznych celów wobec Arabii i Indii może zrealizować tylko wtedy, gdy potwierdzi swoją niekwestionowaną pozycję hegemona w Zatoce Perskiej. Dlatego też wody zatoki uznała za ,jezioro brytyjskie”. Dbając o swoje interesy oraz nie dopuszczając pozostałych rywali w te rejony Brytyjczycy, począwszy od lat 20. XIX wieku, podpisali kilka porozumień z miejscowymi szajchatami, a na wodach zatoki zakotwiczyli swoją flotę wojenną ${ }^{22}$. Należy podkreślić, iż bezpośrednio Anglicy nie okupowali żadnego terytorium w zatoce. Czynili to sprytnie przy pomocy lokalnych autonomicznych szejków, którymi posługiwali się w celu kontroli regionu i nie pozwalali obcym wtargnąć na swój teren, co mieli zagwarantowane w zawartych z nimi umowach.

Mimo, iż Anglia czyniła wszystko, by nie dopuścić pozostałych wielkich mocarstw w region zatoki, to jednak odczuwała stałe zagrożenie ze strony Rosji, Francji, a przede wszystkim Niemiec, zwłaszcza w końcówce XIX wieku i na początku $\mathrm{XX}$ wieku ${ }^{23}$. Rosjanie doprowadzili do tego, że między Odessą a Kuwejtem pływały statki pasażerskie, a Buszahrze, Basrze i Bandar Abbas dążyli do powołania swoich konsulatów w mimo, iż w miastach tych nie było obywateli rosyjskich. Z kolei Niemcy próbowali przeniknać na te tereny poprzez czynny udział w rozbudowie linii kolejowej Berlin-Bagdad ${ }^{24}$. Wszystkie te i podobne próby Londyn odbierał jako bezpośrednie zagrożenie dla swoich interesów w zatoce i Indiach. Późniejsze porozumienia z Francją (1904) i Rosją (1907) spowodowały, iż poważnym zagrożeniem dla polityki brytyjskiej stanowiły Niemcy i sytuacja ta nie ulegnie zmianie aż do wybuchu I wojny światowej ${ }^{25}$. Celem zmniejszenia obcych wpływów w rejonie Zatoki Perskiej Wielka Brytania zwiększyła swoje oddziaływanie na poszczególne szajchaty, by w większym stopniu ustabilizować swoją pozycję i utwierdzić się w roli hegemona na tym obszarze.

${ }^{21}$ E. M. Earle, Turkey, The Great Powers..., s. 196.

22 D. Howarth, The Desert King, Ibn-i Saud and His Arabia, New York 1964, s. 31.

23 J. Zdanowski, Arabia Saudyjska, Warszawa 2004, s. 78-80; tegoż, Emiraty..., s. 81-83.

${ }^{24}$ Por. A. P. Maloney, The Berlin-Baghdad railway as a cause of world war I, Professional Paper 401, 1984, s. $1-23$.

${ }^{25}$ G. Troeller, The Birth of Saudi Arabia..., s. 5, 6. 
Inny wymiar miała polityka brytyjska prowadzona $\mathrm{w}$ stosunku do imperium osmańskiego, polegała bowiem na utwierdzeniu swojej pozycji w tym rejonie poprzez zawieranie nowych porozumień z miejscowymi szejkami. Miały one zapewnić im decydujący i ostateczny głos w przypadku, gdyby miało dojść do przekazania danego terytorium podmiotowi trzeciemu ${ }^{26}$. Należy podkreślić, że od samego począt$\mathrm{ku}$ istniała ostra rywalizacja o przejęcie kontroli nad tymi rejonami między Wielką Brytanią a Turcją. W przeciwieństwie do pozostałych wielkich mocarstw europejskich Konstantynopol nie postrzegał siebie jako najeźdźcy. Z punktu widzenia osmańskiego to Brytyjczycy występowali w roli najeźdźcy. Jeszcze na długo przed czasami Abdülhamida II nieoficjalnie postrzegali Anglię, jako zagrożenie i próbowali przeciwstawić się ekspansji brytyjskiej poprzez zwiększenie swej kontroli i wpływów $\mathrm{w}$ tym regionie.

Podobna linię polityczną Turcy stosowali również w stosunku do Jemenu, Transjordanii i Libii, a służyć miały ku temu reformy tanzimatu, których głównym celem miała być konsolidacja imperium, przeciwstawienie się obcym wpływom, zarówno na arenie wewnętrznej, jak i międzynarodowej. Jednocześnie wyżej wymienione prowincje były zewnętrznymi granicami imperium osmańskiego i liną obrony przed najazdami agresorów. Realizując ten schemat polityczny pod wodzą gubernatora Bagdadu Midhata paszy (1869-1872)27 w 1871 roku doszło do kampanii wojskowej skierowanej przeciwko Brytyjczykom, w wyniku której północe szajchaty nad Zatoką Perską (Kuwejt, Hasa, Katar i Nadżd) zostały ponownie włączone do państwa osmańskiego. Po powrocie Midhata paszy do Konstantynopola, Abdülhamid II kontynuował politykę konsolidacji i ekspansji w zatoce, szczególnie po dramatycznych stratach na Bałkanach w wyniku wojny z Rosją (1877-1878) ${ }^{28}$. Permanentny stan zagrożenia ze strony tureckiej wisiał nad Anglią aż do I wojny światowej, kiedy to Porta wycofała się z tego regionu.

Elementem, który jednoczył pozostałe wielkie mocarstwa i Porte w walce przeciwko Wielkiej Brytanii w tym rejonie była budowa kolei bagdadzkiej. Pierwszoplanową rolę odgrywali tu Niemcy. Zaangażowanie Berlina w sprawy na Środkowym Wschodzie nie wynikało tylko ze względów ekonomicznych i ambicjonalnych, ale miało nader praktyczny i czysto strategiczny wymiar. Niemcy dążyli w ten sposób do aktywizacji polityki osmańskiej w tym regionie, co miało zakwestionować supremację brytyjską nad Zatoką Perską. Szeroko posunięta rozbudowa linii kolejowej w kierunku zatoki miała przyczynić się do szybszego transportu wojsk tureckich w te rejony, co w bezpośredni sposób godziło w interesy Anglików. Dlatego też w tych zmaganiach próbowali wszelkich środków, które skutecznie mogły powstrzymać zapędy Konstantynopola ${ }^{29}$.

\footnotetext{
${ }^{26}$ R. Kumar, India and..., s. 124.

27 G. Ágoston, B. A. Masters, Encyclopedia of the Ottoman Empire, New York 2009, s. 378.

${ }^{28}$ M. Yapp, British Policy in..., s. 81; J. Goldberg, The Foreign Policy..., s. 34.

${ }^{29}$ R. Kumar, India and ..., s. 4; J. Goldberg, The Foreign Policy..., s. 34.
} 
Jednym ze środków było posługiwanie się lokalnymi liderami jako swoimi protegowanymi. Wszystko odbywało się na zasadzie ,pokojowej penetracji”. Dostojnicy osmańscy zdawali sobie sprawę z tak prowadzonej przez Brytyjczyków polityki, lecz ich próby przeciwstawiania się temu na nic się zdały. Pozostawiając na boku zakres znaczeniowy „pokojowej penetracji” czy „rodzaju wpływów”, należy podkreślić, iż Anglicy skutecznie korzystali z usług miejscowych szejków w walce z Turkami o wpływy w rejonie Zatoki Perskiej. Podobny schemat postępowania można było zauważyć w innych częściach imperium osmańskiego, jak np. wykorzystywanie ludności wyznania chrześcijańskiego w różnego rodzaju zamieszkach i wystąpieniach antytureckich. W rejonie zatoki przywódcy szajchatów posiadali szeroko pojętą autonomię oraz mieli za sobą poparcie Brytyjczyków, dlatego też Porta widziała w nich niebezpieczny element grożący destabilizacją całego imperium. Największe zagrożenie płynęło z Bahrajnu posiadającego protekcję Londynu. Ale i w pozostałych szajchatach oraz szejkach Osmanowie nie mogli do końca polegać i nie byli pewni ich lojalności (Kuwejt i szejch (tur. şeyh) Ibn-i Reşid również z poparciem brytyjskim). Większość tureckich mężów stanu było przekonanych, że Anglicy udzielali miejscowym szejkom szerokiego poparcia i zachęcali ich do występowania przeciw zwierzchniej władzy Konstantynopola, a ci z kolei z brytyjskim poparciem w łatwy sposób mogli zakwestionować zwierzchnictwo Porty.

Obszar Zatoki Perskiej, geopolitycznie położony idealnie, stanowił dla Turków osmańskich dogodny punkt, z którego mogli kontrolować ziemie całego imperium, a zwłaszcza Arabię. W tym kontekście wzmocnienie (przez Brytyjczyków) każdej lokalnej siły było postrzegane przez Porte, jako zagrożenie ich zwierzchności nad rejonem Arabii. Dotyczyło to zwłaszcza Hidżazu. Bliskość Zatoki Perskiej z Hidżazem w sposób szczególny niepokoił Turków zważywszy na ogromne wpływy brytyjskie w tym regionie. Dlatego osmańskie władze zwierzchnie obawiały się poważnych konsekwencji, jakie niosła za sobą obecność Anglików w Hidżazu i pozostałych częściach imperium. Należy bowiem pamiętać, że Hidżaz od wieków odgrywał bardzo ważną rolę w umysłach Osmanów. Jeden z najbardziej prominentnych reformatorów okresu tanzimatu, Mustafa Resid pasza zauważył, że imperium osmańskie opierało się na trzech głównych filarach. Islam, jako ten najważniejszy, kalifat jako sługa i protektor Mekki i Medyny oraz Konstantynopol, jako stolica państwa. Nie było to rzecz jasna epokowe odkrycie, ale kierowało uwagę na internalizację klasycznych narzędzi legitymizacji władzy oraz przyszłość kraju. Jego wypowiedzi stanowiły kontynuację klasycznej mentalności osmańskiej ${ }^{30}$.

W epoce panowania Abdülhamida II znaczenie Hidżazu gwałtownie wzrosło, posłużył on bowiem jako legitymizacja kalifatu osmańskiego i rządów osmańskich

${ }^{30}$ W książce pt.: Şemailname, Taliki-zade Mehmed Kemal el-Fenari, wyraził pogląd, że państwo osmańskie opierało się na 20 filarach. Islam, Mekka i Medyna należały do najważniejszych. Należy pamiętać, że w XVI wieku Turcy osmańscy walczyli z Portugalczykami głównie w obronie Hidżazu. Jak dla Brytyjczyków „klejnotem w koronie” były Indie, tak dla imperium osmańskiego „klejnotem korony kalifackiej" (Cevher-i İklil-i Hilafet-i Seniyye) był Hidżaz. Zatem utrzymanie zwierzchnictwa nad Hidżazem było fundamentalnym obowiązkiem wszystkich kalifów osmańskich. 
w Arabii. Zwierzchnictwo nad Hidżazem intensyfikowało również prestiż Osmanów wewnątrz imperium, jak i poza jego granicami oraz służyło jako instrument do ekspansji wpływów religijnych na obszarach nie należących do wyznawców islamu. Dla sułtana utrzymanie Hidżazu wraz z kalifatem stanowiło zadanie nadrzędne, bowiem można było użyć ich w walce $\mathrm{z}$ wielkimi mocarstwami oraz zachęcić ludność muzułmańską zamieszkującą ich kolonie do zaangażowania się w ruch panislamski ${ }^{31}$.

Hidżaz, w kategoriach odległości geograficznych, mienił się jako najważniejszy obszar w imperium osmańskim. Watro nadmienić, iż granice w Arabii opierały się przede wszystkim na lojalności poszczególnych ludów, a nie na wytyczonych liniach politycznych na mapie. Zatem niewielka zmiana w sojuszach między poszczególnymi ludami mogła doprowadzić do ogromnych zmian na scenie politycznej w całej Arabii. Bliskość zatoki i Hidżazu oraz niepewność związana z lojalnością szejków arabskich mogących ulec całkowitym wpływom brytyjskim pomnażała obawy Porty, co do ich przyszłego statusu.

Niemniej Turcy nie byli zupełnie bezbronni, posiadali bowiem kilka linii obronnych (Jemen, Syria, a także Zatoka Perska) związanych z utrzymaniem zwierzchnictwa nad Hidżazą. Znaczenie Zatoki Perskiej w zachowaniu przewodnictwa nad Hidżazą łatwiej zrozumieć, gdy weźmie się pod uwagę, że nawet tereny północnej i centralnej Afryki stanowiły „główną linię obrony” panowania nad Hidżazą i Arabią. Dlatego też władze tureckie z uwagą przyglądały się rozwojowi wypadków w rejonie zatoki, które mogły mieć bezpośrednie przełożenie na Hidżaz. Porta była świadoma zagrożeń, jakie niosła za sobą obecność brytyjska na tym terenie, a przez to możliwość zakwestionowania przez autonomicznych szejków rządów osmańskich nad Hidżazą. Ich niepokój wynikał głównie ze zwiększających się wpływów wahabitów z Nadżu, którzy na początku XIX wieku najechali Hidżazę i sprofanowali święte miejsca muzułmańskie. O tym zdarzeniu osmańscy politycy nigdy nie zapomnieli ${ }^{32}$.

Waśnie i nieporozumienia pomiędzy lokalnymi szejkami w rejonie Zatoki Perskiej mogły mieć bezpośredni wpływ na Hidżaz. W rezultacie konflikt między Ibn-i Reşidem a Mübarek El-Sabah (Mubarak IbnSabah) ocenionoby, biorąc pod uwagę jego następstwa, negatywnie. Gdyby Ibn-i Reşid zaatakował Kuwejt, wówczas Wielka Brytania powołując się na umowę z 1899 roku, udzieliłaby wsparcia Kuwejtowi. Z kolei napaść na Mübareka el-Sabaha mogła dać Brytyjczykom sposobność do ustanowienia strefy wpływów i narzucenia swojej woli pozostałym szejkom. Sytuacja taka z pewnością miałby bezpośredni wpływ na Hidżaz. Zdając sobie z tego sprawę Porta wydała wyraźny rozkaz gubernatorowi (vali) Basry, by ten zapobiegł wszelkim tarciom między obu szejkami i nie dopuścił do interwencji brytyjskiej33.

${ }^{31}$ F. A. K. Yasamee, Ottoman Diplomacy..., s. 26, 46, 49.

${ }^{32}$ K. Karpat, The Politicization of Islam..., s. 258.

33 J. Zdanowski, Emiraty..., s. 91-97. Podobne obawy zaobserwowano w 1904 roku, gdy doszło do walki między Ibn-i Saudem a Ibn-i Reşidem. Wzrost znaczenia Abdülaziza Ibn-i Sauda (Abd al-Aziz Ibn Abd ar-Rahman) i jego zmagania z Ibn-i Reşidem poważnie zaniepokoiły Porte, gdyż istniało poważne niebezpieczeństwo zajęcia Mediny przez Abdülaziza. Wcześniej podbił Qasim, leżące niedaleko Medyny i Basry, a realna możliwość pokonania Ibn-i Reşida otwierała mu drogę do Hidżazu. Na podob- 
Brytyjczycy różnymi sposobami przenikali w rejon zatoki m. in. poprzez dozbrajanie miejscowej ludności, handel bronią, zmuszanie ich do działania w zgodzie z interesami angielskimi, a do tego wszystkiego używali własnych statków, o czym władze tureckie doskonale wiedziały oraz zdawały sobie sprawę, że tego typu działania mogą w znacznym stopniu osłabić ich znaczenie na tym obszarze. W 1887 roku gubernator Basry, Nafiz pasza, informował rząd w Konstantynopolu, że Brytyjczycy czynią wszystko, by przejąć kontrolę nad Zatoką Perską. Twierdził, że Anglicy posługując się wszelkimi sposobami i metodami dążą do podporządkowania sobie rejonów leżących wzdłuż wybrzeża, takich jak Bahrajn i Katar. Wielka Brytania z pełnym wyrachowaniem prowadziła politykę „kija i marchewki” w zależności od aktualnie panującej sytuacji. Innymi słowy, stosowała metody gróźb i nagród, co w końcowym efekcie miało doprowadzić do całkowitego uzależnienia lokalnych szejków, a w następstwie do wykorzystania ich w walce z Portą.

Osmańskie elity państwowe, zarówno te centralne, jak i peryferyjne, były żywo zainteresowane znalezieniem środków, z pomocą których mogłyby skutecznie przeciwstawić się polityce brytyjskiej. Istniało kilka ogólnych zaleceń, które powinny były zostać podjęte przeciwko stale narastającemu zagrożeniu ze strony Londynu. Wśród nich mówiono o pozbawianiu stanowisk lokalnych przywódców uciskających ludność, rozprawę z bandami i innymi przestępcami oraz szeroko pojętą współpracę z miejscową ludnością. Turcy rozważali przy tym wariant „,reform” lub „siły”. Ta druga opcja wiązała się z udziałem operacji wojskowych i zmuszania ludzi do działania w zgodzie z interesami imperium osmańskiego i stanowiła realne niebezpieczeństwo, iż przyniesie to odwrotny skutek od zaplanowanego. Za reformami opowiadała się administracja osmańska, argumentując, że ich wprowadzenie podniesie rangę i autorytet państwa w oczach lokalnych szejków, a wysłanie okrętów tureckich na wody zatoki przyczyni się do osłabienia pozycji brytyjskiej. Jednakże brak środków finansowych na wysłanie statków oraz sprzeciw ze strony lokalnych przywódców, żarliwie popieranych przez Brytyjczyków, w znacznym stopniu osłabiły pozycję Konstantynopola. Taki stan rzeczy trwał do końca ery Abdülhamida II.

ne następstwa zwrócił także uwagę gubernator (muhafiz) Hidżazu, Osman Nuri pasza, który był przekonany, że Qasim stanowiło główny punkt na drodze do podboju Hidżazu, por. G. Troeller, The Birth of Saudi Arabia..., s. 8; R. Kumar, India and..., s. 138. 


\title{
ON THE SHORES OF THE PERSIAN GULF. BRITISH-OTTOMAN RELATIONS DURING THE REIGN OF ABDUL HAMID II (1876-1909)
}

\author{
ANDRZEJ MALINOWSKI
}

Summary

The importance of the Persian Gulf region dates back to the 16th century. The strategic salience of the Persian Gulf increased with the Western (Portuguese) incursions into India in the 16th century. There was a competition between several Western powers such as Portugal versus Britain, Holland versus Britain and Britain versus France to gain control over the Gulf. The Ottoman Empire had entered into the scene with the beginning of the Portuguese interventions to the region. The Ottoman forces conquered Arabia and the Persian Gulf during the era of the Süleyman I. The influence of the Ottomans had loosened to a great extent in the following ages. Britain emerged as the winner of the showdown among the Western Great Powers in the Gulf in the 19th century and subsequently it established its supremacy over the region.

The Anglo-Ottoman relations relations greatly deteriorated with the beginning of Abdülhamid II's rule. The British menace to the Ottoman existence in the Gulf was the consequence of the shift in the British policy aiming at the breakdown and disintegration of the Ottoman Empire. Evidence of the British threat to the Ottoman presence in the region was that Britain, in principle, did not want any challenge to its supremacy in the region, so it thwarted all foreign interventions into the Gulf.

The main purpose of this article is an attempt to present the relationship that have occurred between London and Constantinople during the reign of Abdülhamid II in this region and showing the effects of the British policy, which greatly limited the Ottoman sovereignty in the area. 